\title{
ТИПОЛОГІЯ К. Г. ЮНГА В ПРОФОРІЄНТАЦІЙНІЙ РОБОТІ З УЧНЯМИ ВИПУСКНИХ КЛАСІВ ЗАГАЛЬНООСВІТНЬОї ШКОЛИ
}

\begin{abstract}
Резюме. У нашому суспільстві часто ігнорують питання про правильне використання людиною своїх можливостей. Люди часто займаються не своєю справою і, як наслідок, це негативно відбивається власне на них і на результатах їх діяльності. Тому визначаючи для себе ссреру діяльності, необхідно враховувати свої індивідуальні особливості й спрямовувати їх у правильне русло. Це питання $є$ особливо актуальним для випускників загальноосвітньої школи, які вже зараз обирають майбутню професію.

Мета дослідження - теоретично обґрунтувати та емпірично дослідити провідні психічні фрункції старшокласників (за К. Г. Юнгом) та на цій підставі розробити рекомендації щодо вибору ними майбутньої професії.

Матеріали і методи. Об'єктом вивчення була особистість старшокласника. У процесі роботи використано теоретичні та емпіричні методи, а також методи математичної обробки даних.

Результати досліджень та їх обговорення. У результаті теоретичних досліджень з'ясовано сутнісні аспекти виокремлення психотипу особистості, в основі якого лежить домінування тих чи інших психічних фрункцій (за К. Г. Юнгом). Емпірично встановлено, що спосіб визначення психотипу комбінованим методом (за подвійним анкетуванням та знайомством 3 короткими описами психотипів) $є$ недостатнім для визначення психотипу в старшокласників (психотип визначено лише у 46,9 \% опитаних). Обґрунтовано, що такий підхід можна застосовувати при визначенні виду профресійної діяльності в процесі профорієнтаційної роботи у школі (таку установку визначено у 84,4 \% респондентів). Серед опитаних виявлено: осіб із соціальною установкою на вид діяльності - 7,4 \%, гуманітаріїв - 37,0 \%, керівників - 29,6 \%, науковців -26,0 \%. У 46,9 \% опитаних визначили психотип на основі того, що при опитуванні запропонованим методом результат співпадав двічі або частіше. На підставі аналізу результатів теоретичного та емпіричного дослідження запропоновано комплексний психодіагностичний підхід із метою професійної орієнтації учнів.

Висновки. Розроблено зручний у користуванні комплексний методичний підхід для визначення установки на вид діяльності учнів випускних класів середньої школи, адаптований до застосування в умовах школи. На підставі використання цього підходу в профорієнтаційній роботі зі старшокласниками укладено рекомендації щодо вибору ними майбутньої професії.
\end{abstract}

Ключові слова: особистість; професійна орієнтація; психологічний тип.

ВСТУП Сьогодні в нашому суспільстві часто ігнорують питання про адекватне використання людиною своїх можливостей. Люди часто займаються не своєю справою i, як наслідок, це негативно відбивається власне на них і на результатах їх діяльності. Тому визначаючи для себе сферу діяльності, необхідно враховувати свої індивідуальні особливості й спрямовувати їх у правильне русло.

Це питання $€$ особливо актуальним для випускників загальноосвітньої школи, які вже зараз обирають майбутню профресію. При цьому не завжди задумуються над тим, як їхні індивідуальні особливості відповідають обраному виду діяльності.

Допомогти учням у виборі професії покликана профорієнтація. На сьогодні у середній освіті України вона полягає в ознайомленні юнаків та дівчат зі змістом різних професій і рідко стосується визначення індивідуальних особливостей учнів та їх відповідності до обраного напрямку діяльності.

Дж. Холланд у 1966 р. розробив концепцію, яка об'єднала теорію особистості з теорією вибору професії. Основним положенням теорії $€$ те, що напрямок професійної діяльності визначають такі фрактори, як ціннісні орієнтації, інтереси, установки, мотиви [1]. На їх визначенні ґрунтується професійна діагностика особистості, яку може надати підготовлений спеціаліст на основі проведення численних тестів. Тому загальновизнані профорієнтаційні методики часто $€$ доволі складними та їх важко застосовувати для профдіагностики випускників середньої школи.

Оскільки свідомий та обґрунтований вибір професії базується на врахуванні особистістю своїх індивідуальних властивостей, то важливо знати і використовувати певні психологічні підходи до визначення. У психології визнаний типологічний підхід швейцарського психолога К. Г. Юнга, що базується на диференціації людей за чотирма осно- вними психічними функціями. Психологічний тип - це структура, каркас особистості, який визначає особливості мислення і поведінки, способи усвідомлення світу, себе і свого зв'язку з цим світом, організації життя, а також установку на вид діяльності - спрямованість на виконання своєї соціальної місії [2-4] (табл. 1).

3 погляду типології К. Г. Юнга, кожна людина має не тільки індивідуальні риси, але і риси, властиві одному 3 психологічних типів.

Цей підхід у подальшому розвинений і удосконалений його послідовниками [5]. У результаті в кінці XX ст. сорормувалась наука "Соціоніка".

Знання свого типу особистості допомагає людям знайти саме свої засоби для досягнення мети, бути успішними в житті, вибираючи найбільш прийнятні види діяльності та досягаючи в них найкращих результатів. Утім можна констатувати, що на сьогодні типологічний підхід К. Г. Юнга не набув широкого використання в профорієнтаційній роботі зі старшокласниками.

Метою дослідження було теоретично обґрунтувати та емпірично дослідити провідні психічні фрункції старшокласників (за К. Г. Юнгом) та на цій підставі розробити рекомендації щодо вибору ними майбутньої професії.

МАТЕРІАЛИ І МЕТОДИ Об'єктом дослідження стала особистість 62 учнів 11 класу Тернопільської Української гімназії імені І. Франка. Методи дослідження: теоретичні: теоретичний аналіз психолого-педагогічної літератури, узагальнення та систематизація результатів дослідження; емпіричні: спостереження, бесіда, аналіз опису психотипу, психодіагностичні (питальник В. Гуленка та методика Вайсбанда); методи математичної обробки отриманих даних.

В опитуванні взяли участь 62 учні 11 класів Тернопільської Української гімназії імені І. Франка протягом 2015-2016 н. p. 
Таблиця 1. Сучасні назви психотипів

\begin{tabular}{|c|c|c|c|c|}
\hline № 3/п & Психологічний тип & $\begin{array}{l}\text { Грасрічне зображен- } \\
\text { ня сильних фрункцій }\end{array}$ & $\begin{array}{c}\text { Скорочена та спеціальна } \\
\text { назви }\end{array}$ & $\begin{array}{c}\text { Назва за відомою персоною, } \\
\text { яка мала цей психотип }\end{array}$ \\
\hline 1 & Логіко-сенсорний екстраверт & & ЛСЕ, “Адміністратор” & Штірліц \\
\hline 2 & Логіко-інтуїтивний екстраверт & & ЛІЕ, “Підприємець” & Джек Лондон \\
\hline 3 & Логіко-сенсорний інтроверт & & ЛСІ, “Інспектор" & Максим Горький \\
\hline 4 & Логіко-інтуїтивний інтроверт & & ЛІІ, "Аналітик” & Робесп'єр \\
\hline 5 & Етико-сенсорний екстраверт & & ЕСЕ, "Ентузіаст" & Гюго \\
\hline 6 & Етико-інтуїтивний екстраверт & & EIE, “Наставник” & Гамлет \\
\hline 7 & Етико-сенсорний інтроверт & & ЕСІ, "Хранитель" & Драйзер \\
\hline 8 & Етико-інтуїтивний інтроверт & & EII, "Гуманіст" & Достоєвський \\
\hline 9 & Сенсорно-логічний екстраверт & & СЛЕ, "Маршал" & Жуков \\
\hline 10 & Інтуїтивно-логічний екстраверт & & ІЛЕ, “Новатор" & Дон Кіхот \\
\hline 11 & Сенсорно-логічний інтроверт & & СлІ, “Майстер” & Габен \\
\hline 12 & Інтуїтивно-логічний інтроверт & & ІЛІ, "Критик" & Бальзак \\
\hline 13 & Сенсорно-етичний екстраверт & & СЕЕ, “Політик” & Наполеон \\
\hline 14 & Інтуїтивно-етичний екстраверт & & IEE, "Порадник" & Гекслі \\
\hline 15 & Сенсорно-етичний інтроверт & & СЕI, “Посередник" & Дюма \\
\hline 16 & Інтуїтивно-етичний інтроверт & & IEI, “Лірик” & Єсєнін \\
\hline
\end{tabular}

Емпіричне дослідження проходило у кілька етапів.

На першому етапі проводили обстеження старшокласників із використанням таких питальників:

- питальник В. Гуленка (має 72 блоки, в кожному блоці по 2 твердження, з яких треба вибрати одне);

- питальник Вайсбанда (4 блоки по 2 твердження в кожному).

Питальники склали провідні спеціалісти з соціоніки, $€$ уніфіковані й представлені в Інтернеті.

У процесі тестування респондент, відповівши на усі запитання, отримує на екрані комп'ютера назву свого психотипу та його опис.

На другому етапі дослідження учням давали прочитати короткі (на 6-8 рядків кожен) описи усіх 16 психотипів. Опитані повинні були вибрати 1-2 (або більше) описів, які, на їх думку, їм найбільше підходять.

На третьому етапі результати двох опитувань та ревізії описів психотипів зіставляли між собою. Таким чином, у кожного учня було як мінімум три результати опитування: два - за анкетуванням й одне або більше
- за описами психотипів. Якщо результати двох і більше опитувань співпадали, вважали, що психотип учня встановлено. Якщо ж результати відрізнялись, визначали установку на вид діяльності за двома провідними психічними фрункціями. Для цього графічно відображали сильні фуункції блока Его кожного визначеного психотипу за результатами двох анкетувань і усіх психотипів, визначених учнем за описами. Підраховували, які дві фрункції переважали кількісно, їх вважали провідними.

На четвертому етапі з метою зіставлення установки на вид діяльності та бачення майбутньої профресії учнями, ставили їм два запитання:

- яку просресію планують обрати;

- яка причина вибору професії.

На п'ятому заключному етапі обраховували відсоткові співвідношення визначених результатів.

РЕЗУЛЬТАТИ ДОСЛІДЖЕНЬ ТА ЇХ ОБГОВОРЕННЯ У результаті теоретичних розвідок з'ясовано сутнісні аспекти виокремлення психотипу особистості, в основі якого лежить домінування тих чи інших психічних функцій 
(за К. Г. Юнгом) [6]. Емпірично встановлено, що спосіб визначення психотипу комбінованим методом (за подвійним анкетуванням та знайомством 3 короткими описами психотипів) $є$ недостатнім для визначення психотипу в старшокласників (психотип визначено лише у 46,9 \% опитаних). Обґрунтовано, що такий підхід можна застосовувати при визначенні установки на вид професійної діяльності в процесі профорієнтаційної роботи у школі (таку установку визначено у 84,4 \% респондентів). Серед опитаних виявлено: осіб із соціальною установкою на вид діяльності- 7,4 \%, гуманітаріїв - 37,0 \%, керівників - 29,6 $\%$, науковців - 26,0 \%. У 46,9 \% опитаних визначили психотип на основі того, що при опитуванні запропонованим методом результат співпадав двічі або частіше. Серед таких учнів переважали особи з провідними фрункціями логіки та інтуїції. Виявлено певну розбіжність установки на вид діяльності та обраної професії серед значної частини учнів. Емпіричне дослідження мотивації вибору професії показало високий відсоток самореалізації як причини вибору професії серед науковців (75 \%) та гуманітаріїв (50\%). У керівників переважали мотиви про благо народу й держави (32,9 \%) та можливість побудови кар'єри (28,6 \%). Емпірично встановлено, що при самоаналізі учні приймають за свою домінуючу функцію третю (рольову) фрункцію блока Суперего, що може впливати на вибір профресії. Найбільш це характерно для сенсорних типів. Легше відбувається визначення свого психотипу в осіб з провідною фрункцією інтуїції, гірше - сенсорики.

На підставі отриманих результатів запропоновано методичний підхід з метою професійної орієнтації учнів. Підхід, який ми запропонували, включає в себе комп'ютерне опитування за двома питальниками (методики В. Гуленка і Вайсбанда), у результаті чого отримують 2 результати у вигляді назви психотипів. Далі респондента знайомлять 3 описами 16 психологічних типів, з яких він вибирає 1-2, які, з його точки зору, найточніше відповідають його сутності (за неможливості вибрати 1-2 можна вибирати більшу кількість описів). У кожного з визначених психотипів визначають провідні фрункції блока Его. Підраховують кількість кожної функції (етики, логіки, сенсорики, інтуїції) та вибирають дві фрункції, які переважають кількісно. За цими функціями визначають установку на вид діяльності (табл. 2).

Таблиця 2. Провідні функції, що визначають вид діяльності людини

\begin{tabular}{|l|c|}
\hline \multicolumn{1}{|c|}{ Провідна фрункція } & Вид діяльності \\
\hline Логіка, сенсорика & Управлінці \\
\hline Логіка, інтуїція & Науковці \\
\hline Етика, інтуїція & Гуманітарії \\
\hline Етика, сенсорика & Соціали \\
\hline
\end{tabular}

Якщо вибір учнем своєї майбутньої професії не співпадає 3 його установкою на вид діяльності, йому необ- хідно за наявності внутрішньої мотивації на обрання профресії приділити увагу тренуванню слабких психологічних фрункцій, необхідних для даної профресії і/або ж поглибити і розширити самопізнання в контексті професійного самовизначення.

На підставі теоретичного аналізу та емпіричного дослідження ми розробили рекомендації старшокласникам щодо їх професійного самовизначення.

Учням, у яких емпірично встановлено розбіжність установки на вид діяльності та обраної професії і за наявності внутрішнього стійкого мотиву професійного вибору, рекомендовано детальніше проаналізувати, 3 якими проблемами вони можуть зіткнутись, працюючи в обраній галузі, й цілеспрямовано працювати над розвитком в собі відповідних якостей, тренувати слабкі психічні фрункції, необхідні у професійній діяльності. 3 іншого боку, необхідно актуалізувати процеси самоаналізу та самопізнання 3 метою більш свідомого та самостійного професійного самовизначення відповідно до своїх індивідуальних властивостей особистості та інтересів.

ВИСновкИ 1. Спосіб визначення психотипу комбінованим методом (за подвійним анкетуванням та знайомством з короткими описами психотипів) $€$ недостатнім для визначення психотипу в учнів 11 класу загальноосвітньої школи (психотип визначено лише у 46,9 \% опитаних). Проте такий метод можна застосовувати при визначенні установки на вид професійної діяльності в процесі профрорієнтаційної роботи у школі (таку установку визначено у $84,4 \%$ респондентів).

2. У $46,9 \%$ опитаних визначили психотип на основі того, що при опитуванні запропонованим методом результат співпадав двічі або частіше. Серед таких учнів переважали особи з провідними фрункціями логіки та інтуїції. Проте отримані дані потрібно перевірити іншими соціонічними методами, щоб безапеляційно стверджувати, що психотип у цих учнів визначено остаточно.

3. Виявлено певну розбіжність установки на вид діяльності та обраної профресії серед значної частини учнів: у $70 \%$ осіб із гуманітарним напрямком діяльності, $40 \%$ "науковців" та 42,9 \% "управлінців".

4. При опитуванні про причини вибору професії звертає увагу високий відсоток самореалізації, як причини вибору професії серед науковців (75 \%) та гуманітаріїв (50 \%). У керівників переважали думки про благо народу й держави (32,9 \%) та можливість побудови кар'єри (28,6 \%).

Перспективи подальших досліджень Подальше вивчення провідних психічних функцій старшокласників у комплексі психодіагностичних методик із використанням типологічного підходу К. Г. Юнга дасть змогу розробити рекомендації щодо вибору ними майбутньої профресії. Отримані результати вказують на необхідність подальших досліджень у розробці ефективних методик вивчення професійної орієнтації старшокласників.

\section{СПИСОК ЛІТЕРАТУРИ}

1. Зеер Э. Ф. Профориентология : теория и практика : учеб. пособ. / Э. Ф. Зеер, А. М. Павлова, Н. О. Садовникова. - М. : Академический Проэкт; Фонд "Мир”, 2008. - 192 с.

2. Гуленко В. В. Структурно-функциональная соционика : разработка метода комбинаторики полярностей / В. В. Гуленко. - К. : Транспорт України, 1999. - 187 с.
3. Каганець І. В. Психологічні аспекти в менеджменті: типологія Юнга, соціоніка, психоінфоорматика / І. В. Каганець. - К. : Тернопіль, Мандрівець, 1997. - 204 с.

4. Прокофьева Т. Н. Соционика. Алгебра и геометрия человеческих взаимоотношений / Т. Н. Прокофьева. - 2-е изд., стереотипное. - М. : Алмаз, 2005. - 112 с. 
5. Прокофьева Т. Н. Психологические типы К. Г. Юнга / Т. Н. Прокофьева. - [Електронный ресурс]. - Режим доступа http://www.socionics.ru/ung.htm
6. Юнг К. Г. Психологические типы / К. Г. Юнг ; ред. В. Зеленского. - Спб. : Азбука, 2001.- 216 с.

Отримано 03.01.18

\author{
(CM. I. Horishnyi, I. M. Horishnyi \\ I. Horbachevsky Ternopil State Medical University
}

\begin{abstract}
TYPOLOGY OF K.G. JUNG IN VOCATIONAL GUIDANCE WORK WITH STUDENTS OF GRADUATE CLASSES AT HIGH SCHOOL
\end{abstract}
Summary. In our society, the issue of proper use of human opportunities is often ignored. People often deal with not their business, and as a result, it negatively affects on their own interests and on the results of their activities. This question is especially actually for graduates of a high school, who are choosing a future profession.

The aim of the study - to substantiate theoretically and explore empirically the leading mental functions of high school of students (by K. G. Young) and, on this basis, to develop recommendations for choosing of their future profession.

Materials and Methods. The object of research was the personality of the senior pupil. In the process of scientific work we used the theoretical and empirical methods, as well as methods of mathematical processing of data.

Results and Discussion. As a result of theoretical research the essential aspects of the identification of the individual psychotype, which is based on the domination of certain psychic functions (by K. G. Young) were investigated. Empirically there was explored that determining of psychotype by the combined method (by double questionnaires and brief descriptions of psychotypes) is not sufficient for the definition of psychotype in senior pupils (psychotype was defined only in $46.9 \%$ of respondents). It is substantiated that such method can be used in determining the type of professional activity in the process of vocational guidance work at school (such results were determined in $84.4 \%$ of respondents). Among the respondents there were revealed: persons with a social attitudes for the type of activity $-7.4 \%$, humanists $37.0 \%$, headmans/managers $-29.6 \%$, scientists $-26.0 \%$. In $46.9 \%$ of cases there were identified the psychotype based on the fact that according to proposed method the results coincided twice or more times. Based on the analysis of the results theoretical and empirical research the complex psychodiagnostic method was proposed for the purpose to determine professional orientation of students.

Conclusions. Complex method for the determination of activity type in graduates of high school, adapted and easy for use in school conditions was developed. Based on the use of this method in professional guidance in work with students that graduate high school could make recommendations for choosing their future profession.

Key words: personality; professional orientation; psychological type.

ФМ. И. Горишный, И. М. Горишный

ГВУз “Тернопольский государственный медицинский университет имени И. Я. Горбачевского”

\title{
ТИПОЛОГИЯ К. Г. ЮНГА В ПРОФОРИЕНТАЦИОННОЙ РАБОТЕ С УЧАЩИМИСЯ ВЫПУСКНЫХ КЛАССОВ ОБЩЕОБРАЗОВАТЕЛЬНОЙ ШКОЛЫ
}

Резюме. В нашем обществе часто игнорируют вопрос о правильном использовании человеком своих возможностей. Люди часто занимаются не своим делом и, следовательно, это негативно отражается собственно на них и на результатах их деятельности. Поэтому определяя для себя сферу деятельности, необходимо учитывать свои индивидуальные особенности и направлять их в правильное русло. Этот вопрос особенно актуален для выпускников общеобразовательной школы, которые уже сейчас выбирают будущую профрессию.

Цель исследования - теоретически обосновать и эмпирически исследовать ведущие психические фуннции старшеклассников (по К. Г. Юнгу) и на этом основании разработать рекомендации по выбору ими будущей профессии.

Материалы и методы. Объектом изучения была личность старшеклассника. В процессе работы использованы теоретические и эмпирические методы, а также методы математической обработки данных.

Результаты исследований и их обсуждение. В результате теоретических исследований установлены сущностные аспекты выделения психотипа личности, в основе которого лежит доминирование тех или иных психических функций (по К. Г. Юнгу). Эмпирически установлено, что способ определения психотипа комбинированным методом (по двойному анкетированию и знакомству с краткими описаниями психотипов) является недостаточным для определения психотипа у старшеклассников (психотип определен только в 46,9 \% опрошенных). Обосновано, что такой подход может применяться при определении установки на вид профессиональной деятельности в процессе профрориентационной работы в школе (такую установку определено в 84,4 \% респондентов). Среди опрошенных выявлено: людей с социальной установкой на вид деятельности - 7,4 \%, гуманитариев - 37,0 \%, руководителей - 29,6\%, ученых - 26,0\%. В 46,9 \% опрошенных определили психотип на основе того, что при опросе предложенным методом результат совпадал дважды или чаще. На основании анализа результатов теоретического и эмпирического исследования предложен комплексный психодиагностический подход с целью профессиональной ориентации учащихся.

Выводы. Разработан удобный в пользовании комплексный методический подход для определения установки на вид деятельности учащихся выпускных классов средней школы, адаптированный к применению в условиях школы. На основании использования этого подхода в профориентационной работе со старшеклассниками созданы рекомендации по выбору ими будущей профессии.

Ключевые слова: личность; профессиональная ориентация; психологический тип. 